\title{
Higher fine-scale genetic structure in peripheral than in core populations of a long-lived and mixed-mating conifer - eastern white cedar (Thuja occidentalis L.)
}

Madhav Pandey ${ }^{1,2}$ and Om P Rajora ${ }^{1 *}$

\begin{abstract}
Background: Fine-scale or spatial genetic structure (SGS) is one of the key genetic characteristics of plant populations. Several evolutionary and ecological processes and population characteristics influence the level of SGS within plant populations. Higher fine-scale genetic structure may be expected in peripheral than core populations of long-lived forest trees, owing to the differences in the magnitude of operating evolutionary and ecological forces such as gene flow, genetic drift, effective population size and founder effects. We addressed this question using eastern white cedar (Thuja occidentalis) as a model species for declining to endangered long-lived tree species with mixed-mating system.

Results: We determined the SGS in two core and two peripheral populations of eastern white cedar from its Maritime Canadian eastern range using six nuclear microsatellite DNA markers. Significant SGS ranging from $15 \mathrm{~m}$ to $75 \mathrm{~m}$ distance classes was observed in the four studied populations. An analysis of combined four populations revealed significant positive SGS up to the $45 \mathrm{~m}$ distance class. The mean positive significant SGS observed in the peripheral populations was up to six times (up to $90 \mathrm{~m}$ ) of that observed in the core populations $(15 \mathrm{~m}$ ). Spatial autocorrelation coefficients and correlograms of single and sub-sets of populations were statistically significant. The extent of within-population SGS was significantly negatively correlated with all genetic diversity parameters. Significant heterogeneity of within-population SGS was observed for 0-15 $\mathrm{m}$ and 61-90 m between core and peripheral populations. Average $S p$, and gene flow distances were higher in peripheral $\left(S p=0.023, \sigma_{g}=135 \mathrm{~m}\right)$ than in core $\left(S p=0.014, \sigma_{g}=109 \mathrm{~m}\right)$ populations. However, the mean neighborhood size was higher in the core $(\mathrm{Nb}=82)$ than in the peripheral $(\mathrm{Nb}=48)$ populations.

Conclusion: Eastern white cedar populations have significant fine-scale genetic structure at short distances. Peripheral populations have several-folds higher within-population fine-scale genetic structure than core populations. Anthropogenic disturbances and population fragmentation presumably have significant effects on fine-scale genetic structure in eastern white cedar. Core populations have higher neighborhood size than peripheral populations, whereas gene flow distances are higher in peripheral than in core populations. The results of our study contribute to the knowledge of poorly-understood spatial genetic structure of core versus peripheral populations in plants. As well, the information is of significance for conservation of genetic resources of eastern white cedar and perhaps of other long-lived forest trees with mixed-mating system.
\end{abstract}

\footnotetext{
* Correspondence: Om.Rajora@unb.ca

${ }^{1}$ Canadian Genomics and Conservation Genetics Institute, Faculty of Forestry and Environmental Management, University of New Brunswick, 28 Dineen Drive, Fredericton, NB E3B 5A3, Canada

Full list of author information is available at the end of the article
}

\section{(Ciomed Central}

(c) 2012 Pandey and Rajora; licensee BioMed Central Ltd. This is an Open Access article distributed under the terms of the Creative Commons Attribution License (http://creativecommons.org/licenses/by/2.0), which permits unrestricted use, distribution, and reproduction in any medium, provided the original work is properly cited. 


\section{Background}

Recently, in addition to core, peripheral populations are also gaining importance for gene conservation, because under global climate change conditions they may possess genotypes of future adaptive potential. Plant populations tend to migrate further from their range periphery to ensure their survival by developing adaptability in a changing environmental condition due to global warming [1]. Genetic studies involving both core and peripheral populations are still limited [2]. Additionally, the available studies mainly focused on withinand among-population genetic diversity [2-4], and majority of them reported higher genetic diversity and lower population differentiation in core than in peripheral populations. Although still limited, there are increasing reports on SGS in fragmented versus continuous populations e.g., [5-7]. However, information on the comparison of SGS between core and peripheral populations of plant species is almost non-existent. The only published report on this aspect by Gapare \& Aitken [8] reported significantly higher SGS in peripheral and random distribution of genotypes in core populations of predominantly outcrossing conifer, Sitka spruce (Picea sitchensis). The level of SGS within plant populations depends on seed and pollen dispersal, mating system, mode of reproduction, size of the founder population, species longevity, adult population density, effective population size, and micro environmental selection [9-13]. Anthropogenic disturbance and fragmentation of populations can also influence SGS by restricting gene flow and increasing local drift due to severe modification of forest environment and ecosystem, and density of populations $[14,15]$. Information on SGS levels in core and peripheral populations can unravel differential effect of the key evolutionary and ecological genetic processes operating in natural plant populations, such as gene dispersal, natural selection and genetic drift. Analysis of SGS is also important for understanding the population dynamics of a species as its response to microenvironmental variation and global climate change $[16,17]$. Furthermore, knowledge of SGS in natural populations is also important for developing scientifically-sound sampling strategies for genetic resource conservation and breeding purposes.

Higher SGS may be expected in peripheral than in core populations of long-lived plants, such as forest trees, owing to the differences in founding population, seed and pollen dispersal, adult plant density, inbreeding levels, effective population size $\left(N_{e}\right)$, and disturbance and selection regimes. Restricted gene flow due to limited seed and pollen dispersal can promote mating among relatives which can result in isolation by distance within a population [18]. Therefore, a local genetic subdivision can develop SGS within populations. Selfing and other forms of inbreeding can limit gene dispersal, consequently influencing the spatial distribution of genetic variation within populations [16]. In contrast, generally, outcrossing decreases population subdivision by reducing mating among relatives and increasing $N_{e}$ [10]. Therefore, higher level of SGS can be expected in inbreeding species as compared to outcrossing species. Vegetative clonal reproduction can significantly affect the SGS through the development of spatial clusters of the members of a clone [19]. Long-lived plants are expected to have low levels of SGS within their populations because of decreased population divergence due to increased $N_{e}$ and decreased genetic drift over time [10]. SGS has been found to be inversely correlated with adult density within populations [20]. Additionally, the levels of SGS were found to be positively correlated with the level of fragmentation of plant populations e.g., $[6,14,21]$.

Conifers are generally long-lived plants that are ecologically and economically important globally. They constitute a major component of the northern boreal and temperate forests, especially dominating the boreal forest which comprises one of the largest biomes in the world http://www.borealforest.org/index.php?category=world_boreal_forest\&page=overview. Most of the conifer tree species are characterized by predominantly $(\sim 90 \%)$ outcrossing mating system. Studies in conifers reported either no or weak levels of SGS within populations [21-32]. This is consistent with the conifers' characteristics of predominant outcrossing, wind-pollination and seed dispersal by wind. Except for two studies [24,32], all of the SGS studies in conifers are reported for Pinus or Picea species. Furthermore, with the exception of two $[8,28]$, all other studies on SGS in conifers are based on only one or two populations. All of the SGS studies in conifers have been reported for predominantly outcrossing $(\geq 90 \%)$ species, and there is no SGS information on plant species that have mixed-mating system with high selfing levels.

Eastern (or northern) white cedar (Thuja occidentalis L.) provides an ideal model species to study SGS in core versus peripheral populations of declining and longlived plant species with mixed mating system. Eastern white cedar is a wind-pollinated, monoecious, evergreen tree species belonging to the Cypress family (Cupressaceae). It reproduces both sexually and vegetatively. Vegetative reproduction occurs mainly in swampy sites by layering [33]. Eastern white cedar is an ecologically and economically important tree species, highly suitable for many wood products. Since its foliage is a favorite winter food for deer, it is very important for wildlife conservation. It can reach an age of 400 years [34]. 
The natural distribution range of eastern white cedar extends from Manitoba east to Nova Scotia, and south into the Great Lakes Regions of the United States, east to New England, with southern disjunct populations in the Appalachians in North Carolina and Tennessee ([34]; Figure 1). Eastern white cedar reaches its eastern periphery in Nova Scotia and the Prince Edward Island (PEI), where it occurs in small, scattered and fragmented

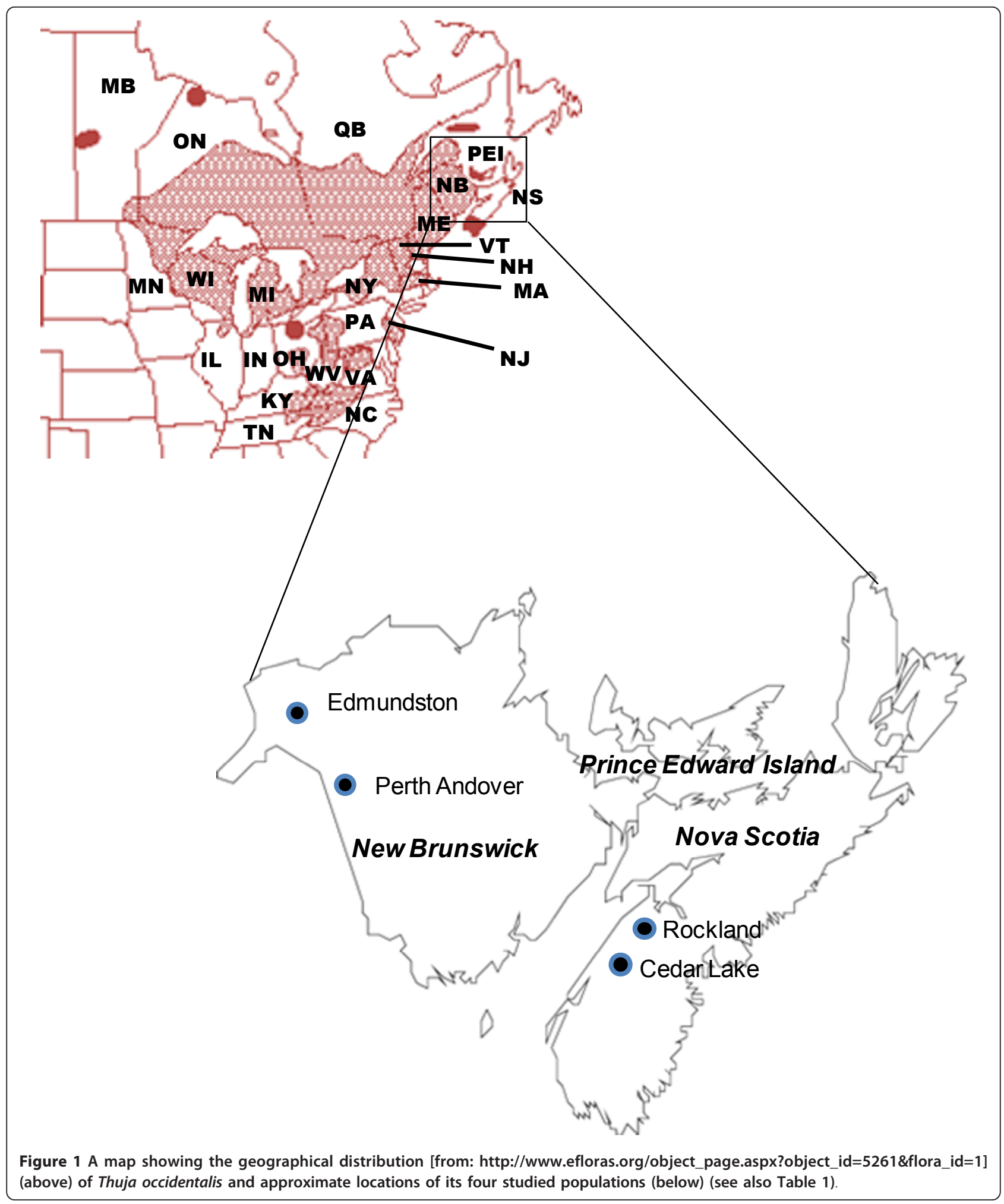


populations [34,35]. Historical records indicate that the range and number of populations of eastern white cedar have diminished due to logging, and clearing for agriculture over the past 400 years in Nova Scotia and PEI $[33,35]$. Presently, there are only 32 identified populations of eastern white cedar in Nova Scotia [34], which are highly fragmented. Due to its rarity in Nova Scotia, eastern white cedar has been designated as a Red (endangered) species in this province. In Prince Edward Island, occurrence of eastern white cedar is limited to only a few populations, mainly found in the western part of the Island (West of Summerside). Eastern white cedar is common in New Brunswick, where it forms its best development [35]. Thus, New Brunswick represents the core or central range of this species. However, here also eastern white cedar has been listed as a species of concern.

Like other cedar species (Thuja plicata, T. orientalis, [36-38]), eastern white cedar also possesses relatively low genetic diversity [39-41]. It is characterized by a mixed-mating system with high levels (mean 54\%) of selfing rates $[41,42]$. Although a few genetic diversity studies have been conducted in the genus Thuja [36-41,43], to our best knowledge, there is no information available on SGS in any Thuja species. The only SGS study in the Cupressaceae family was done for one population of an outcrossing species, Cryptomeria japonica [32], which reported significant SGS at short distance classes (up to $60 \mathrm{~m}$ ) based on nuclear microsatellites, but non-significant SGS for chloroplast microsatellites.

The aim of the present study was to determine withinpopulation fine-scale genetic structure of eastern white cedar growing in core and peripheral populations. Our hypotheses were: (i) since eastern white cedar is a mixed-mating long-lived tree with high levels of selfing rate, and has capability to reproduce vegetatively, this species is expected to have some levels of SGS within population; (ii) the peripheral populations of eastern white cedar are expected to have higher levels of SGS than the core populations due to their lower population density; potentially restricted gene dispersal, smaller $N_{e}$, and higher anthropogenic fragmentation as compared to the core populations [9-13].

\section{Methods}

\section{Populations and sampling}

Four natural populations of eastern white cedar were sampled from two Maritime Provinces of Canada. Two of these were core (Edmundston and Perth Andover) populations from New Brunswick and other two were peripheral (Cedar Lake and Rockland) populations from Nova Scotia (Figure 1; Table 1). We restricted sampling of the core and peripheral populations to the same
Maritime region of eastern Canada to avoid other regional and ecological effects confounding the results. The two populations sampled in New Brunswick are located in the central part of the species' range. Despite some harvesting activities, eastern white cedar populations remain intact with contiguous distribution in this province with no barrier to gene flow between populations. On the other hand, the two eastern white cedar populations sampled from Nova Scotia are disjunct, and highly fragmented and disturbed as they have experienced anthropogenic disturbances over a long period of time. It was not possible to find undisturbed pristine natural populations of eastern white cedar in both core and peripheral regions in eastern Canada. Also, fragmented core and contiguous peripheral populations could not be found in our study region. All of the sampled populations are over 100 years old. The populations sampled in Nova Scotia were from almost pure eastern white cedar stands, whereas the populations sampled from New Brunswick are mixed with other tree species, such as black spruce (Picea mariana) and balsam fir (Abies balsamea).

A plot consisting of $\sim 100$ contiguous eastern white cedar trees was established in each of the four sampled populations irrespective of the plot area (Figure 2). All of the eastern white cedar individuals were sampled within these plots. We chose this sampling strategy to keep the sample size equal among all four sampled populations, in order to minimize the effects of sample size confounding the comparison of SGS results between the populations. Spatial locations of each of the sampled trees were recorded as their geo-coordinates using a Geographical Positioning System (Garmin GPS MAP 60CSx). The spatial location maps of the sampled trees in each of the four populations are provided in Figure 2.

Small amounts of foliage samples were collected from each of the 394 sampled trees in plastic Ziplock bags containing silica gel. Upon arrival to the lab, the foliage samples were stored at $-20^{\circ} \mathrm{C}$ until processed for DNA extraction.

\section{DNA extraction and genotyping}

Total genomic DNA was extracted from the needle samples of individual trees using the DNeasy Plant Mini Kit (Qiagen, USA). Microsatellite DNA markers of the nuclear genome were used for genotyping the sampled trees. A total of 40 microsatellite markers developed for the Cupressaceae species were tested in eastern white cedar. Of these, 37 were developed for Thuja plicata [44,45], [L.M. O'Connell \& C.E. Ritland, Unpublished data; C.J. Newton, Unpublished data] and three for Chameacyparis obtusa [46]. Only six (TP1, TP2, TP4, TP6, TP11 and $91 \mathrm{G}$ ) of the 40 microsatellites yielded simple 
Table 1 Geographical location, sample size and stand density of four sampled populations of eastern white cedar

\begin{tabular}{|c|c|c|c|c|c|c|c|}
\hline Province & Population & Code & Range location & Latitude (N) & Longitude (W) & No. of individuals sampled & Stand density (Trees/ha) \\
\hline New Brunswick & Edmundston & ED & Core & $47^{\circ} 33^{\prime} 16^{\prime \prime}$ & $68^{\circ} 13^{\prime} 53^{\prime \prime}$ & 100 & 46.72 \\
\hline New Brunswick & Perth Andover & PA & Core & $46^{\circ} 44^{\prime} 53^{\prime \prime}$ & $67^{\circ} 42^{\prime} 34^{\prime \prime}$ & 100 & 58.82 \\
\hline Nova Scotia & Cedar Lake & $\mathrm{CL}$ & Peripheral & $44^{\circ} 50^{\prime} 22^{\prime \prime}$ & $65^{\circ} 01^{\prime} 48^{\prime \prime}$ & 100 & 18.20 \\
\hline Nova Scotia & Rockland & $\mathrm{RL}$ & Peripheral & $45^{\circ} 00^{\prime} 35^{\prime \prime}$ & $64^{\circ} 42^{\prime} 10^{\prime \prime}$ & 94 & 24.00 \\
\hline
\end{tabular}

and scorable PCR (Polymerase Chain Reaction) products. These six microsatellites were optimized and used for genotyping individual eastern white cedar trees. PCR amplifications were carried out using $10 \mu \mathrm{l}$ reaction mixtures containing 20 to $30 \mathrm{ng}$ of genomic DNA, $1 \times$ PCR buffer, $1.5 \mathrm{mM} \mathrm{MgCl} 2,0.20 \mathrm{mM}$ of each dNTP, 0.50 pmol of each primer and $0.25 \mathrm{U}$ Taq DNA polymerase (Invitrogen, USA). The epGradients Master Cycles (Eppendorf, Germany) were used for PCR amplification of the sample DNA, with the following thermocycling profile: initial denaturation step at $95^{\circ} \mathrm{C}$ for $5 \mathrm{~min}$, followed by 33 cycles each of $95^{\circ} \mathrm{C}$ for $45 \mathrm{sec}$, annealing temperature at 55 to $65^{\circ} \mathrm{C}$ for $45 \mathrm{sec}, 72^{\circ} \mathrm{C}$ for $45 \mathrm{sec}$ and final extension step of $72^{\circ} \mathrm{C}$ for $5 \mathrm{~min}$. PCR products were separated on LI-COR4300 genetic analyzers (LI-COR Inc. Lincoln, Nebraska, USA). The genotypes of individual trees were first determined by scoring the LI-COR gels with the SAGA GT program
Edmundston (ED)

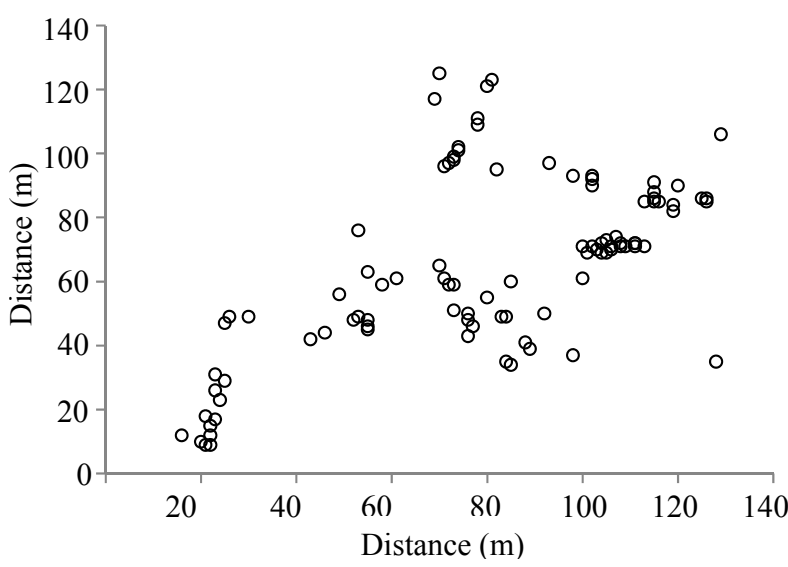

Cedar Lake (CL)

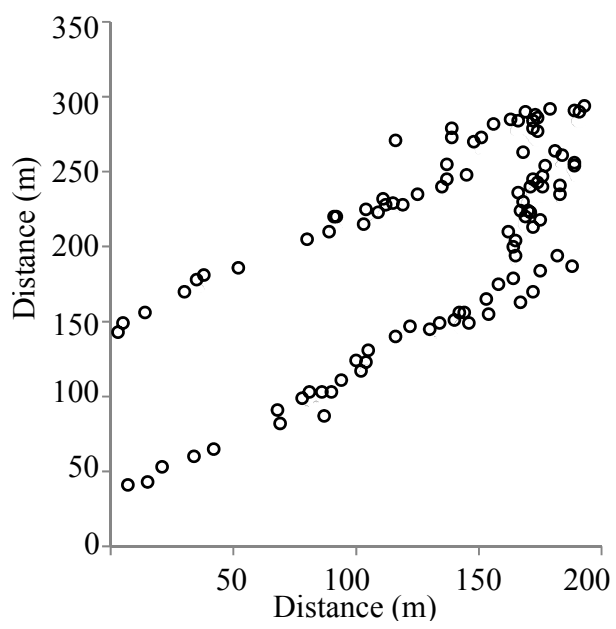

Perth Andover (PA)

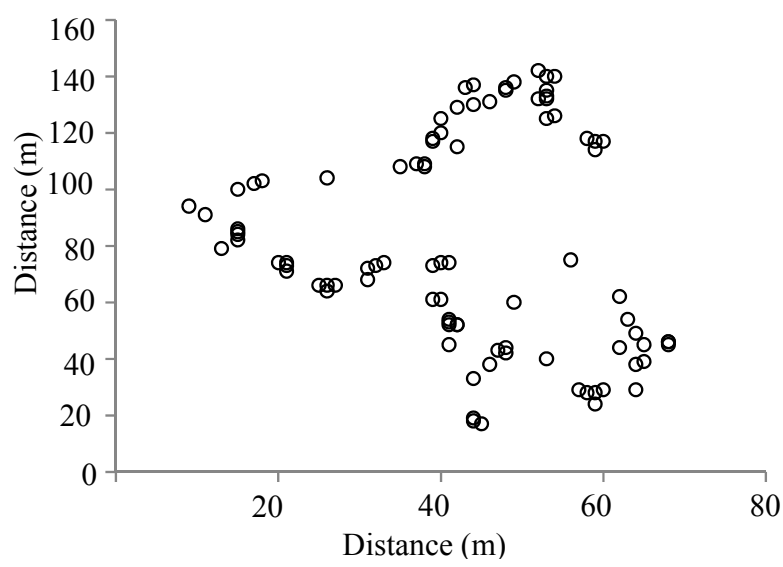

Rockland (RL)

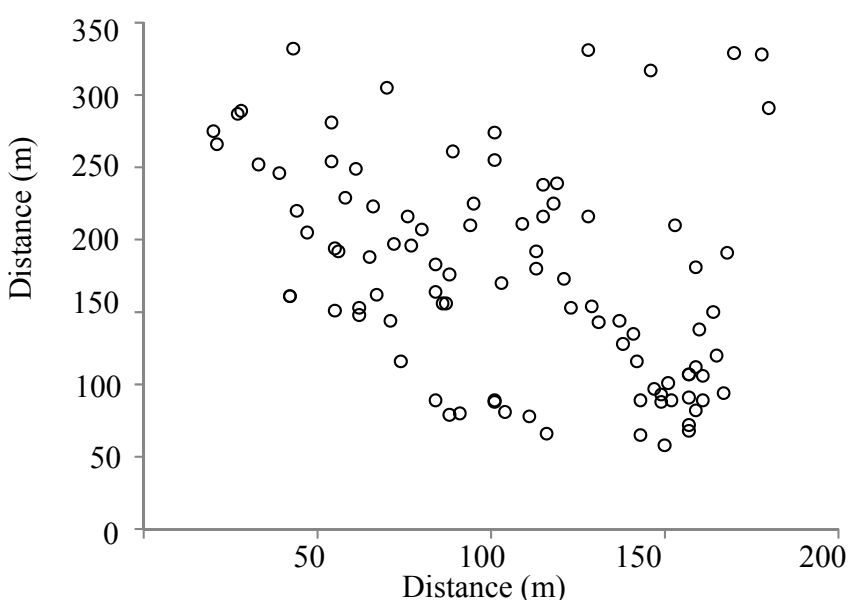

Figure 2 Spatial distribution of individual trees in each of the four studied eastern white cedar populations. 
(LI-COR Inc. Lincoln, Nebraska, USA) and later verified by manual scoring.

\section{Statistical data analysis Genetic diversity and $\mathrm{N}_{e}$}

The standard population genetic diversity parameters (number of alleles, observed and expected heterozygosity) and fixation index $(F)$ were calculated using the program GENALEX [47]. Allelic richness $\left(A_{R}\right)$ was estimated using the program FSTAT [48]. Genotypic diversity was determined by calculating observed and expected genotype additivity $\left(\mathrm{GA}_{\mathrm{O}}\right.$ and $\left.\mathrm{GA}_{\mathrm{E}}\right)$ as the sum of genotypes observed and expected under Hardy-Weinberg equilibrium over the loci [49]. Deviations of genotypic frequencies from the Hardy-Weinberg expectation were tested using the Markov chain method (parameter values: dememorisation number $=10,000$, number of batches $=300$, number of iterations per batch $=5,000$ ) in the GENEPOP program [50].

The effective population size $\left(N_{e}\right)$ for each of the four populations was estimated using the maximum likelihood method of coalescent-theory and MIGRATE program [51]. At first, the $\theta$ values were estimated for each population using MIGRATE program and assuming an average microsatellite mutation rate of $10^{-3}$ per generation. The $N_{e}$ was calculated as $\theta /\left(4 \times 10 .^{-3}\right)$.

\section{Spatial distribution}

Pattern of spatial distribution of individual trees in the four eastern white cedar populations were estimated using univariate second-order Ripley's [52] $\mathrm{K}$-function for $10,15,20$ and $30 \mathrm{~m}$ distance classes (t). The weighted edge correction [53] method was applied to correct the edge effect. Monte Carlo procedure was used to test the significance of deviation from a random distribution at $95 \%$ upper and lower confidence envelops, generating 10,000 replications. These calculations were performed using the SPPACK program [54].

\section{Spatial Genetic Structure (SGS)}

We used Smouse and Peakall's [12] spatial autocorrelation method to estimate the SGS in the four eastern white cedar populations employing the GENALEX 6.2 [47] program. This method determines spatial distribution of genetic variation based on a frequencyweighted average over all alleles and loci and correlation coefficients of genotypes in relation to their spatial distance. It allows for the covariance between alleles (see [12] for detailed description). In order to facilitate the comparison of SGS among the four populations, we used $15 \mathrm{~m}$ distance class as representative because three, out of the four populations showed maximum values of Ripley's $K$ at this distance class. Similar approach was used by Oddou-Muratorio et al. [55] to select the distance class for SGS analysis in a tree species, Sorbus torminalis.
In addition to the estimation of multilocus SGS parameters for each of the four populations separately, SGS analyses were also performed for combined subset each of core (ED, and PA), and peripheral (CL and RL) populations, as well by combining all four populations to infer degrees of heterogeneity of SGS within and between subsets based on the method of Smouse et al. [56] using GENALEX 6.2 program. These analyses permit us to formally test whether differences in SGS between the subsets of populations are statistically significant. Since the analysis of SGS using combined multiple populations increases sample sizes, it increases statistical power of the analysis to detect the presence of SGS within populations. Heterogeneity tests for single and multi-populations correlograms were performed as described by Smouse et al. [56]. This method first performs the heterogeneity test of autocorrelation coefficient among individuals lag-by-lag using the pooled within-population correlograms. Then the single-lag tests are used to perform an analogous heterogeneity test of multilag correlograms (see Smouse et al. [56] for detailed description). Single class $\left(t^{2}\right)$ and multi-class $(\omega)$ test criteria were used to test the heterogeneity of spatial autocorrelation $(r)$ values between single and subsets of populations. Heterogeneity in SGS for single distance classes between any two populations or a subset of populations was determined by performing the squared paired-sample $t$ test $\left(t^{2}\right)$ [56]. SGS heterogeneity over all distance classes (a) in a population and (b) among populations was determined by using the $\omega$ test criteria [56] under the null hypotheses that (a) there is no significant spatial autocorrelation at any distance class, and that (b) the spatial correlograms from all populations are homogeneous. Statistical significance of all the analyses was performed by permutation test with 9,999 replications at the $95 \%$ upper and lower confidence intervals.

The correlations of the SGS parameters (significant spatial autocorrelation coefficient, $r$ ) with $N_{e}$ (actual or log transformed), genetic diversity parameters and density of eastern white cedar trees within the sampled populations were determined by calculating the Pearson correlation coefficients $(R)$, using the MINITAB 15 package.

\section{$S p$ statistics and dispersal estimates}

In order to quantify SGS and to compute neighborhood sizes and gene dispersal distances in the four eastern white cedar populations, $S p$ statistic was estimated as follows: $S p=-{ }^{\wedge} \mathrm{b}_{\mathrm{F}} /\left(1{ }^{\wedge} F_{1}\right)$, where $-{ }^{\wedge} \mathrm{b}_{\mathrm{F}}$ is the regression slope of the autocorrelogram and ${ }^{\wedge} F_{1}$ is the mean kinship coefficient (Fij) [57] between individuals belonging to the first $(0-15 \mathrm{~m})$ distance class [21]. Using the $S p$ statistics, Wright's neighborhood size $\mathrm{Nb}(\mathrm{Nb}=1 / \mathrm{Sp})$ 
was also estimated. $N b$ is defined as $N b=4 \pi D_{e} \sigma_{\mathrm{g}}{ }^{2}$, where $\sigma_{\mathrm{g}}{ }^{2}$ is the axial variance of gene dispersal and $D_{e}$ the effective population density. Estimates of gene dispersal distance $(\sigma \mathrm{g})$ were determined assuming ratios of effective to census density, $D e / D$, of 0.1 and $0.5[7,21]$. Estimates of ${ }^{\wedge} \mathrm{b}_{\mathrm{F}}$ and ${ }^{\wedge} F_{1}$ were carried out using SPAGEDI program [58]. Statistical significance $(P \leq 0.05)$ of the analyses was performed by permutation tests with 10,000 replications.

\section{Results}

\section{Genetic diversity and effective population size}

In total, 95 alleles were observed at six microsatellite loci in four eastern white cedar populations. The core populations showed higher allelic as well as genotypic genetic diversity than the peripheral populations (Table 2 ). Also, the core populations possessed higher number of private alleles than the peripheral ones (Table 2). The two core populations from New Brunswick (ED and PA) showed very similar levels of genetic diversity. All four populations showed significant deviation from the Hardy-Weinberg equilibrium. The $N_{e}$ was 432 and 910, with an average of 671 in the core populations, and 110 and 310, with an average of 210 in the peripheral populations (Table 2). As the objective of this study was to determine SGS, we do not focus on discussing genetic diversity results here. Results on genetic diversity and population structure of 13 eastern white cedar populations from the same region are presented and discussed elsewhere [59].

\section{Spatial distribution}

Results of spatial distribution pattern analysis using Ripley's $K$-function and the number of pairs of observation for $15 \mathrm{~m}$ distance class are presented in Figure 3, and Table 3, respectively. All four populations showed significant aggregation of individuals at the distance classes $10,15,20$ and $30 \mathrm{~m}$ (results are shown only for $15 \mathrm{~m}$ distance class).

\section{Spatial genetic structure (SGS)}

Results of the multilocus spatial genetic structure (SGS) analysis based on Smouse \& Peakall's [12] spatial autocorrelation coefficient $(r)$ are presented in Figure 4. All four studied populations showed positive significant SGS in short distance classes ranging from $15 \mathrm{~m}$ in ED and PA to $75 \mathrm{~m}$ in RL (Figure 4). Analysis of the combined core (ED and PA) populations showed significant SGS up to $15 \mathrm{~m}$, whereas analysis of the combined peripheral (CL and RL) populations showed significant SGS up to $90 \mathrm{~m}$ (Table 4). An overall significance test $(\omega)$ of spatial autocorrelations and correlograms revealed that all single or combinedpopulations were statistically significant (Table 4).

The maximum values of spatial autocorrelation coefficient $(r)$ were observed for the first $(0-15 \mathrm{~m})$ distance class for individual or combined populations (Table 4). The $r$ values for the first distance class showed great variation among the four populations ranging from 0.030 (PA population) to 0.114 (RL population) (Figure 4). Thus, $r$ in RL was about four times of that in PA. The highest $r$ for the combined peripheral populations $(r=0.093)$ was considerably higher than in the intact populations $(r=0.058)$.

Except for the population pair CL and RL, all pairs revealed significant heterogeneity in SGS between the populations based on the multi-class test criterion $(\omega)$ (Table 4). Significant heterogeneity in SGS was also observed between the core and peripheral populations

Table 2 Genetic diversity measures, fixation index and their (SE), and effective population size for four sampled populations of eastern white cedar

\begin{tabular}{|c|c|c|c|c|c|c|c|c|c|c|c|c|c|}
\hline Pop type & Province & Population & $A_{T}$ & A & $A_{E}$ & $A_{R}$ & $A_{P}$ & $\mathrm{H}_{\mathrm{O}}$ & $\mathrm{H}_{\mathrm{E}}$ & $\mathrm{GA}_{\mathrm{O}}$ & $\mathrm{GA}_{\mathrm{E}}$ & $F$ & $N_{e}$ \\
\hline \multirow[t]{2}{*}{ Core } & $\begin{array}{l}\text { New } \\
\text { Brunswick }\end{array}$ & $E D$ & 63.00 & $\begin{array}{l}10.50 \\
(1.86)\end{array}$ & $\begin{array}{l}4.19 \\
(1.15)\end{array}$ & $\begin{array}{l}10.08 \\
(2.09)\end{array}$ & 11 & $\begin{array}{l}0.640 \\
(0.057)\end{array}$ & $\begin{array}{l}0.662 \\
(0.079)\end{array}$ & $127(3.84)$ & $404(7.43)$ & $\begin{array}{l}0.007 \\
(0.062)\end{array}$ & 432 \\
\hline & & PA & 67.00 & $\begin{array}{l}11.17 \\
(2.63)\end{array}$ & $\begin{array}{l}4.68 \\
(1.51)\end{array}$ & $\begin{array}{l}10.68 \\
(2.51)\end{array}$ & 9 & $\begin{array}{l}0.640 \\
(0.087)\end{array}$ & $\begin{array}{l}0.640 \\
(0.103)\end{array}$ & $145(4.53)$ & $500(9.03)$ & $\begin{array}{l}-0.025 \\
(0.048)\end{array}$ & 910 \\
\hline \multirow[t]{5}{*}{ Peripheral } & Nova Scotia & $\mathrm{CL}$ & 53.00 & $\begin{array}{l}8.83 \\
(2.02)\end{array}$ & $\begin{array}{l}2.79 \\
(0.44)\end{array}$ & $\begin{array}{l}8.42 \\
(2.15)\end{array}$ & 6 & $\begin{array}{l}0.571 \\
(0.070)\end{array}$ & $\begin{array}{l}0.597 \\
(0.060)\end{array}$ & $100(3.12)$ & $312(6.69)$ & $\begin{array}{l}0.050 \\
(0.034)\end{array}$ & 310 \\
\hline & & $R L$ & 47.00 & $\begin{array}{l}7.83 \\
(2.17)\end{array}$ & $\begin{array}{l}2.60 \\
(0.48)\end{array}$ & $\begin{array}{l}7.66 \\
(2.27)\end{array}$ & 5 & $\begin{array}{l}0.505 \\
(0.111)\end{array}$ & $\begin{array}{l}0.519 \\
(0.110)\end{array}$ & 77 (2.94) & $267(7.07)$ & $\begin{array}{l}0.044 \\
(0.048)\end{array}$ & 110 \\
\hline & Mean & Core & 65.00 & $\begin{array}{l}10.83 \\
(2.24)\end{array}$ & $\begin{array}{l}4.43 \\
(1.33)\end{array}$ & $\begin{array}{l}10.38 \\
(2.30)\end{array}$ & 10 & $\begin{array}{l}0.640 \\
(0.072)\end{array}$ & $\begin{array}{l}0.651 \\
(0.091)\end{array}$ & $\begin{array}{l}136.00 \\
(4.19)\end{array}$ & $452(8.23)$ & $\begin{array}{l}-0.009 \\
(0.055)\end{array}$ & 671 \\
\hline & & Peripheral & 50.00 & $\begin{array}{l}8.33 \\
(2.10)\end{array}$ & $\begin{array}{l}2.70 \\
(0.46)\end{array}$ & $\begin{array}{l}8.04 \\
(2.21)\end{array}$ & 5.50 & $\begin{array}{l}0.540 \\
(0.091)\end{array}$ & $\begin{array}{l}0.560 \\
(0.085)\end{array}$ & $\begin{array}{l}88.50 \\
(3.03)\end{array}$ & $\begin{array}{l}289.50 \\
(6.88)\end{array}$ & $\begin{array}{l}0.047 \\
(0.041)\end{array}$ & 210 \\
\hline & $\begin{array}{l}\text { Overall } \\
\text { mean }\end{array}$ & & 57.50 & $\begin{array}{l}9.58 \\
(2.17)\end{array}$ & $\begin{array}{l}3.57 \\
(0.89)\end{array}$ & $\begin{array}{l}9.21 \\
(2.26)\end{array}$ & 7.75 & $\begin{array}{l}0.590 \\
(0.082)\end{array}$ & $\begin{array}{l}0.600 \\
(0.088)\end{array}$ & $\begin{array}{l}112.25 \\
(3.61)\end{array}$ & $\begin{array}{l}370.75 \\
(7.55)\end{array}$ & $\begin{array}{l}0.019 \\
(0.048)\end{array}$ & 440 \\
\hline
\end{tabular}

$A_{T}$, total number of alleles; $A$, mean number of alleles per locus; $A_{E}$, effective number of alleles; $A_{R}$, Allelic richness; $A_{P}$, number of private alleles; GA, observed genotype additivity (richness); $\mathrm{GA}_{E}$, expected genotype additivity [49]; $\mathrm{H}_{\mathrm{O}}$, observed heterozygosity; $\mathrm{H}_{E}$, expected heterozygosity; $F$, fixation index; $N_{e}$, effective population size. Values in parentheses are standard errors.

ED, Emundston; PA, Perth Andover; CL, Cedar Lake; RL, Rockland 


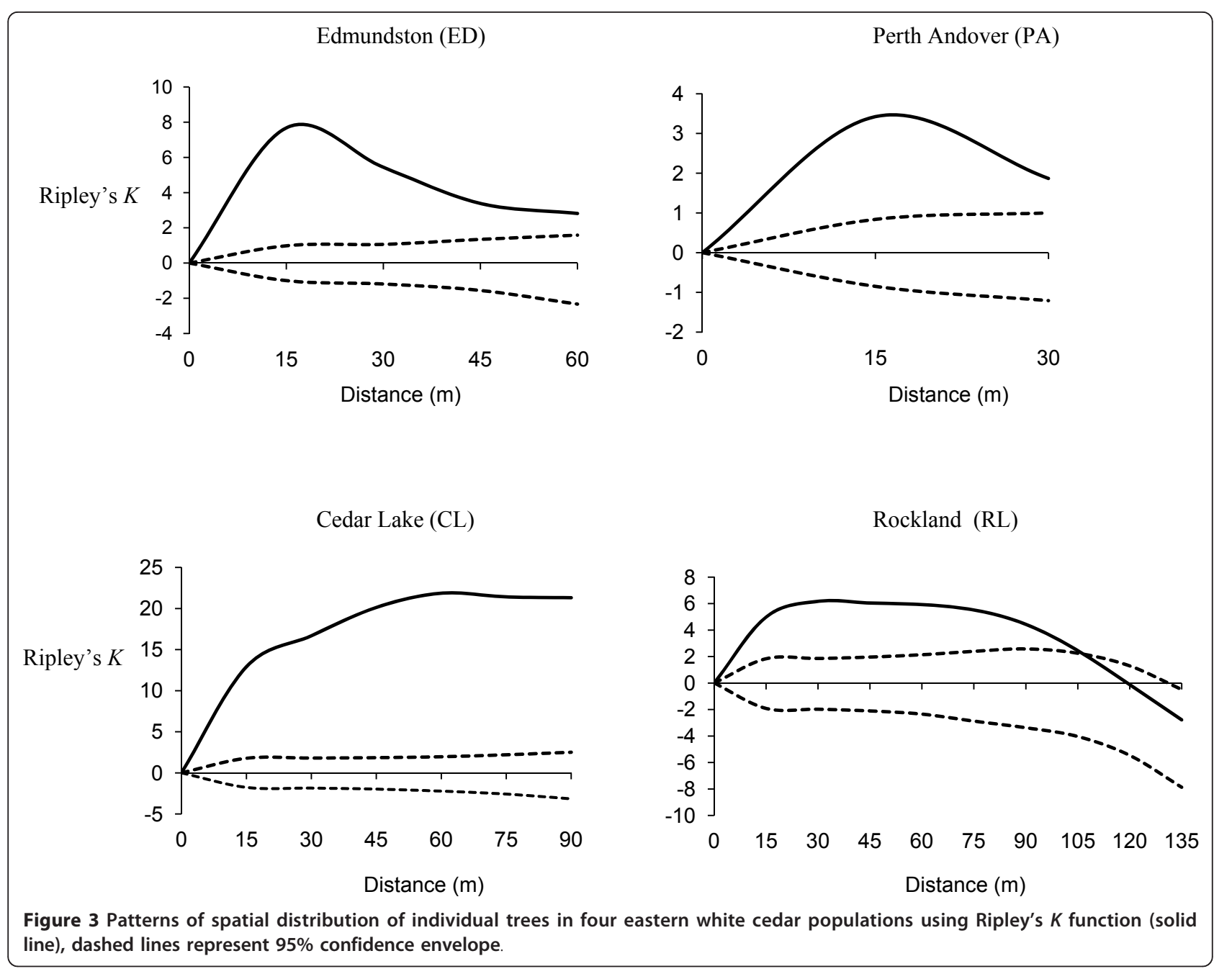

over the $0-15 \mathrm{~m}$ and $61-90 \mathrm{~m}$ distances (up to $90 \mathrm{~m}$ ) (Table 4).

\section{$S p$ statistics and dispersal estimates}

Results of $S p$ statistics and dispersal estimates in the four eastern white cedar populations are presented in Table 5. $S p$ values were 0.009 (PA) and 0.018 (ED) in the core populations, and $0.016(\mathrm{CL})$ and 0.031 (RL) in the peripheral populations. Average $S p$ value was higher in the peripheral $(0.023)$ than in the core $(0.014)$ populations Average value for Wright's neighborhood size $(\mathrm{Nb})$ was higher in the core populations (81.57) as compared to the peripheral populations (48.04). Gene flow distances $\left(\sigma_{\mathrm{g}}\right)$ were 44 and $120 \mathrm{~m}$ in the core populations and 46 and $167 \mathrm{~m}$ in the peripheral populations (Table 5).

\section{Correlations of SGS parameters with genetic diversity, stand density, and population $\mathrm{Ne}$}

There was negative correlation of the significant SGS (spatial autocorrelation coefficient $r$ ) with the population genetic diversity measures. The correlations (Pearson correlation coefficient $\mathrm{R}$ ) of $r$ with genetic diversity measures were as follows: mean number of alleles per locus $($ A $)=-0.85 P=0.034)$, observed heterozygosity $\left(\mathrm{H}_{\mathrm{O}}\right)=$ $0.89(P=0.022)$, expected heterozygosity $\left(\mathrm{H}_{\mathrm{E}}\right)=-0.82$ $(P=0.044)$, observed genotypic richness $\left(\mathrm{GA}_{\mathrm{O}}\right)=-0.88$ $(P=0.024)$ and expected genotypic richness $\left(\mathrm{GA}_{\mathrm{E}}\right)=08$ $P=0.040)$. The correlation of eastern white cedar stand density with $r$ a $-0.69 P=0.096$ ). The significant SGS $r$ values showed negative high correlation (Pearson $\mathrm{R}=$ -0.65)wt $N e$, although the correlation was not statistically significant $(P=0.139)$.

\section{Discussion}

\section{Spatial genetic structure in eastern white cedar}

Our study demonstrates that eastern white cedar has significant within-population fine-scale genetic structure at short distances. This was clearly evident from significant positive SGS at $\sim 15 \mathrm{~m}$ to $\sim 75 \mathrm{~m}$ in four studied eastern white cedar populations; suggesting that 
Table 3 Number of pairs of observation per distance class for the four eastern white cedar populations

\begin{tabular}{lllll}
\hline Distance class $(\mathbf{m})$ & \multicolumn{4}{c}{ Population } \\
\cline { 2 - 5 } & ED & PA & CL & RL \\
\hline $0-15$ & 581 & 651 & 231 & 122 \\
$16-30$ & 768 & 1014 & 345 & 262 \\
$31-45$ & 919 & 700 & 430 & 327 \\
$46-60$ & 1025 & 737 & 473 & 385 \\
$61-75$ & 701 & 816 & 469 & 427 \\
$76-90$ & 307 & 550 & 567 & 432 \\
$91-105$ & 303 & 344 & 435 & 399 \\
$106-120$ & 249 & 126 & 324 & 371 \\
$121-135$ & 89 & 12 & 308 & 381 \\
$136-150$ & 8 & & 271 & 301 \\
$151-165$ & & & 209 & 217 \\
$166-180$ & & & 203 & 181 \\
$181-195$ & & & 158 & 154 \\
$196-210$ & & & 124 & 100 \\
$211-225$ & & & 96 & 116 \\
$226-240$ & & & 63 & 85 \\
$241-255$ & & 49 & 63 \\
$256-270$ & & 41 & 38 \\
$270-285$ & & & 31 & 7 \\
$286-300$ & & 17 & 3 \\
$301-315$ & & & 7 & \\
\hline
\end{tabular}

ED, Emundston; PA, Perth Andover; CL, Cedar Lake; RL, Rockland

individuals with similar alleles or genotypes were more often growing in proximity than expected by chance alone. The extent of the observed significant SGS depended upon the location of the populations (core versus peripheral). These results are discussed later in this section.

The extent of SGS for combined four eastern white cedar populations (up to $45 \mathrm{~m}$ ) is more than two times of that observed in one 20-years old population of another mixed-mating (mean selfing rate of $27 \%$ [60]) species Larix larcinia (up to $20 \mathrm{~m}$ ) [33]. The existence of SGS in Larix larcinia was explained primarily due to the effect of founding population. In contrast, predominantly-outcrossing species showed either weak or no within-population SGS e.g. [17,22,28]. Thus, mixed-mating conifer species tolerating high levels of selfing apparently have higher SGS within their populations than the predominantly outcrossing conifers.

Besides higher levels of selfing or inbreeding, limited gene flow and founding gene pool may be responsible for the observed short-distance SGS in eastern white cedar. Restricted gene flow due to limited pollen and seed dispersal contributes to local grouping of individuals with similar alleles or genotypes [10]. In eastern white cedar, both pollen and seeds are disseminated by wind. We are not aware of any information on the average distance of pollen dispersal in this species. However, in conifers it is well known that pollen is dispersed in enormous amounts over considerable distances $[61,62]$. Therefore, the restriction in gene flow due to limited pollen flow is less likely to happen in eastern white cedar, especially in the contiguous populations. However, in the peripheral populations, reduced gene flow may have contributed to the observed levels of fine-scale genetic structure as a result of fragmentation. Fowells [63] reported a seeding range of up to $60 \mathrm{~m}$ in eastern white cedar under normal conditions. Interestingly, the mean level of SGS observed in eastern white cedar (up to $45 \mathrm{~m}$ ) falls within this range of the seeding distance. Therefore, restricted gene flow due to limited seed dispersal may be one of the main reasons for the observed short-distance SGS in the species.

Vegetative propagation through natural layering has been reported in eastern white cedar $[33,64]$. Since the individuals established from vegetative propagation have genetic constitution identical to the source tree and grow in proximity forming clumps, this may generate a significant SGS at short distance intervals. However, we did not find any concrete evidence for vegetative propagation contributing to the observed levels of SGS in any of the four study populations. We detected only four to eight individuals (4 to $8 \%$ ) per population growing in proximity of each other with the same multilocus genotypes (data not shown). This level of multilocus genotype sharing may be due to vegetative reproduction, selfing, a combination of these factors or just by chance. However, our data does not support vegetative propagation contributing to the observed levels of SGS in eastern white cedar. Although, it is generally expected that vegetative reproduction is one of the major factors that may contribute to the occurrence of significant SGS in vegetatively reproducing species, Chung \& Epperson [65] found little effect of vegetative reproduction on SGS in Eurya emarginata. They explained that the restriction in gene flow due to limited dispersal of seed and pollen could be the main reason for the observed SGS in the species.

\section{Spatial distribution pattern of trees}

The analysis of spatial distribution pattern using Ripley's $K$ function indicated significant aggregation of trees in all four populations of eastern white cedar. Within population spatial patterns of individual plants can be influenced by several factors such as variation in microsites, level of disturbance, seed dispersal patterns [56,66]. Parker et al. [66] and Trabaud et al. [67] reported a significant aggregation of tress in Pinus clausa and Pinus halepensis populations, respectively, and they explained that the observed aggregation could be due to either limited seed dispersal or recruitment of 

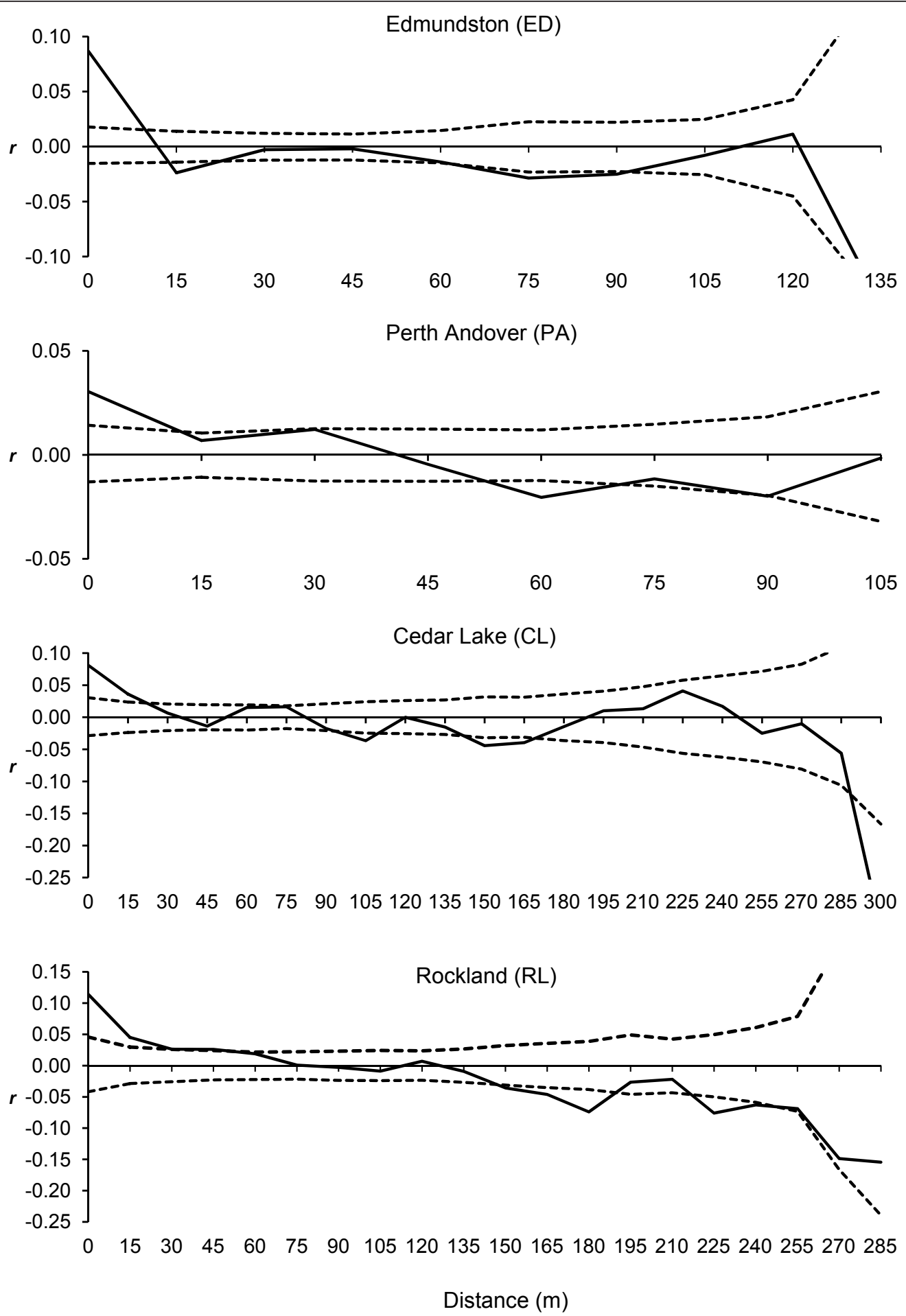

Figure 4 Correlograms of spatial autocorrelation coefficients $(r)$ (solid lines) plotted against geographical distance classes, estimated for four eastern white cedar populations. Dashed lines represent upper and lower $95 \%$ confidence limits.

aggregated seedlings after stand disturbance due to fire. These factors may have contributed to the observed spatial pattern of individual trees in eastern white cedar populations. The effect of limited seed dispersal on the significant aggregation of individual trees may be evident from the significant SGS (15-75 m) observed in the four populations. Although we are not aware of any records of fire in the studied populations, past occurrence of fire 
Table 4 Spatial autocorrelation coefficients $(r)$, single-class squared pair-sample $t$-test $\left(t^{2}\right)$ and multi-class and multipopulation $(\omega)$ heterogeneity tests of spatial autocorrelation coefficients $(r)$ for individual populations, population pairs and subsets of populations

\begin{tabular}{|c|c|c|c|c|c|c|c|c|c|}
\hline \multirow[t]{2}{*}{ Populations } & \multicolumn{8}{|c|}{$\begin{array}{l}r \text { and } t^{2} \text { values and their statistical significance in } \\
\text { different distance classes }\end{array}$} & \multirow[t]{2}{*}{$\begin{array}{l}\text { Overall multi-distance class or multi population correlogram } \\
\text { significance ( } \omega \text {-test criterion) }\end{array}$} \\
\hline & $0-15$ & $16-30$ & $31-45$ & $46-60$ & $61-75$ & $76-90$ & $\begin{array}{l}91- \\
105\end{array}$ & $\begin{array}{l}106- \\
120\end{array}$ & \\
\hline & \multicolumn{8}{|c|}{$\begin{array}{l}\text { Spatial autocorrelation } \\
\text { coefficients }(r)\end{array}$} & \\
\hline ED & $0.087^{*}$ & -0.024 & -0.003 & -0.002 & -0.014 & -0.029 & -0.025 & -0.008 & $75.35^{*}$ \\
\hline PA & $0.030^{*}$ & 0.007 & 0.012 & -0.005 & -0.020 & -0.012 & -0.020 & -0.002 & $70.49^{*}$ \\
\hline$C L$ & $0.081^{*}$ & $0.036^{*}$ & 0.006 & -0.014 & 0.015 & 0.016 & -0.017 & -0.037 & $134.39^{*}$ \\
\hline $\mathrm{RL}$ & $0.114^{*}$ & $0.045^{*}$ & $0.026^{*}$ & $0.026^{*}$ & $0.019^{*}$ & 0.001 & -0.003 & -0.009 & $147.32^{*}$ \\
\hline Core & $0.058^{*}$ & -0.007 & 0.003 & -0.003 & -0.017 & -0.018 & -0.022 & -0.006 & $81.11^{*}$ \\
\hline Peripheral & $0.093^{*}$ & $0.040^{*}$ & $0.016^{*}$ & $0.005^{*}$ & $0.017^{*}$ & $0.009^{*}$ & -0.010 & -0.022 & $154.80^{*}$ \\
\hline \multirow{2}{*}{$\begin{array}{l}\text { Four pops } \\
\text { combined }\end{array}$} & $0.066^{*}$ & 0.005 & $0.007^{*}$ & 0.000 & -0.004 & -0.003 & -0.015 & -0.016 & $65.65^{*}$ \\
\hline & \multicolumn{8}{|c|}{$\begin{array}{l}\text { Single-class squared pair- } \\
\text { sample } t \text {-test }\left(t^{2}\right)\end{array}$} & \\
\hline ED vs. PA & $17.53^{*}$ & $8.44^{*}$ & 1.89 & 0.06 & 0.37 & 1.13 & 0.09 & 3.89 & $47.99^{*}$ \\
\hline ED vs. CL & 0.10 & $17.13^{*}$ & 0.52 & 0.96 & $5.50^{*}$ & $8.03^{*}$ & 0.21 & 0.16 & $51.66^{*}$ \\
\hline ED vs. RL & 1.34 & $18.83^{*}$ & $4.25^{*}$ & $4.70^{*}$ & $6.67^{*}$ & 3.07 & 1.71 & 0.02 & $57.02^{*}$ \\
\hline PA vs. CL & $7.82^{*}$ & $4.54^{*}$ & 0.18 & 0.52 & $8.69^{*}$ & $4.31^{*}$ & 0.02 & 3.57 & $49.70^{*}$ \\
\hline PA vs. RL & $12.76^{*}$ & $6.15^{*}$ & 0.93 & $5.05^{*}$ & $10.11^{*}$ & 0.72 & 1.03 & 4.00 & $62.34^{*}$ \\
\hline CL vs. RL & 1.55 & 0.24 & 1.48 & $7.07^{*}$ & 0.07 & 1.20 & 0.85 & 0.16 & 28.08 \\
\hline $\begin{array}{l}\text { Core vs. } \\
\text { peripheral }\end{array}$ & $4.72^{*}$ & 18.64 & 1.58 & 0.73 & $15.08^{*}$ & $6.83^{*}$ & 1.04 & 1.23 & $65.26^{*}$ \\
\hline
\end{tabular}

ED, Edmundston; PA, Perth Andover; $\mathrm{CL}$, Cedar Lake; RL, Rockland. * indicates significant values $(P \leq 0.05)$

on the studied populations cannot be ruled out because fire is one of the main agents of natural disturbance in boreal forest [68].

\section{SGS in core versus peripheral populations}

The mean significant SGS in the peripheral populations (up to $90 \mathrm{~m}$ ) was up to six times of that was observed in the core $(15 \mathrm{~m})$ populations. The difference in SGS between the core and peripheral populations was statistically significant $(\omega=65.26, P=0.001)$. Both Nova Scotia populations (CL and RL) showed the highest within- population SGS, and the lowest genetic diversity, stand density and $N_{e}$. These populations are highly fragmented and affected by human disturbance for over 400 years ever since the arrival of European settlers in the Province. The several-folds higher SGS levels observed in the two marginal and highly fragmented populations from Nova Scotia is likely due to reduced stand density, gene dispersal, genetic diversity and $N_{e}$ observed in these populations (Tables 1 and 2) as well as increased founder effect and genetic drift due to anthropogenic fragmentation and other disturbances. Thus, the

Table 5 Spatial genetic structure, Sp statistics and estimates of gene flow distances in four eastern white cedar populations

\begin{tabular}{|c|c|c|c|c|c|c|c|c|c|c|c|}
\hline Region & Population & ${ }^{\wedge} \mathrm{F} 1$ & ${ }^{\wedge} F 2$ & ${ }^{\wedge} \mathrm{F3}$ & ${ }^{\wedge} F 4$ & ${ }^{\wedge} F 5$ & $b-\log \left({ }^{\wedge} b F\right)$ & $S p$ & $N b$ & $\sigma_{\mathrm{g}}(\mathrm{m})(D e / D=0.1)$ & $\sigma_{\mathrm{g}}(\mathrm{m})(\mathrm{De} / \mathrm{D}=0.5)$ \\
\hline \multirow[t]{2}{*}{ Core } & ED & $0.047^{*}$ & $-0.013^{*}$ & -0.001 & -0.001 & -0.008 & $-0.017^{*}$ & 0.018 & 56.73 & 98.29 & 43.96 \\
\hline & PA & $0.015^{*}$ & 0.004 & 0.006 & 0.008 & -0.013 & $-0.009^{*}$ & 0.009 & 106.41 & 119.98 & 53.66 \\
\hline \multirow[t]{2}{*}{ Peripheral } & $\mathrm{CL}$ & $0.045^{*}$ & $0.023^{*}$ & 0.003 & -0.008 & -0.005 & $-0.015^{*}$ & 0.016 & 64.00 & 167.32 & 74.83 \\
\hline & $R L$ & $0.070^{*}$ & $0.027^{*}$ & $0.026^{*}$ & $0.015^{*}$ & $0.014^{*}$ & $-0.029^{*}$ & 0.031 & 32.08 & 103.14 & 46.13 \\
\hline Average core & & 0.031 & 0.004 & 0.003 & 0.004 & -0.011 & -0.013 & 0.014 & 81.57 & 109.14 & 48.81 \\
\hline Average peripheral & & 0.057 & 0.025 & 0.015 & 0.004 & 0.005 & -0.022 & 0.023 & 48.04 & 135.23 & 60.48 \\
\hline
\end{tabular}

$\overline{{ }^{\wedge}} \mathrm{F} 1,{ }^{\wedge} \mathrm{F} 2,{ }^{\wedge} \mathrm{F} 3,{ }^{\wedge} \mathrm{F} 4$ and ${ }^{\wedge} \mathrm{F}$ : mean kinship coefficient (Fij) [57] between individuals belonging to the first (0-15 $\mathrm{m}$ ), second (15-30 m), third (30- $\left.45 \mathrm{~m}\right)$, fourth (45-60 $\mathrm{m})$ and fifth $(60-75 \mathrm{~m})$ distance classes, respectively; b-log $\left({ }^{\wedge} \mathrm{bF}\right)$ : Slope of the regression of kinship with $\ln \left(\right.$ dist); $S p$ : statistic defined by the ratio ${ }_{-}{ }^{b F} /\left(1-{ }^{\wedge} F 1\right)$, where ${ }^{\wedge} \mathrm{bF}$ is the regression slope of the autocorrelogram; ${ }^{\wedge} \mathrm{F} 1$ is the mean kinship coefficient (Fij) between individuals belonging to the first (0-15 $\left.\mathrm{m}\right)$ distance class [20]; $N b$ Wright's neighbourhood size; $\sigma \mathrm{g}$, estimate of gene flow distance from $S p$, assuming different ratios of effective (De) to census density (D); *, significant $(P<0.05)$

$E D$, Edmundston; PA, Perth Andover; $C L$, Cedar Lake; RL, Rockland 
magnitude of evolutionary forces operating in core versus peripheral populations is probably different. It was not possible to dissect out the effects of anthropogenic fragmentation and disturbances on SGS in the peripheral populations from that of their peripheral location. Comparisons of SGS between pristine core and pristine peripheral populations would have been ideal. However, in the eastern Maritime Canadian range of eastern white cedar where our study was focused, no peripheral population could be found that is not anthropogenically fragmented and disturbed. Thus, fragmentation and disturbance may also have contributed to higher SGS observed in the peripheral populations. The negative correlations of SGS with stand density, genetic diversity parameters and $N_{e}$ are consistent with the population genetic theories and expectations. The negative correlation between genetic diversity and SGS could be due to the combined effect of founder effects and reduced stand density.

The spatial distribution of genotypes was found to be random in the core populations of Sitka spruce, whereas significant positive SGS up to $500 \mathrm{~m}$ was observed in the peripheral populations of this species [8]. In eastern white cedar, we observed mean significant positive SGS up to $90 \mathrm{~m}$ (combined populations) in the peripheral and up to $15 \mathrm{~m}$ in the core populations. Thus, the magnitude of impact of ecological and evolutionary factors on SGS in peripheral populations of Sitka spruce appears to be much higher than in eastern white cedar. Sitka spruce is a predominantly outcrossing species. The extent of differences observed in within-population SGS in core versus peripheral populations between these species may be related to the differences in their mating system. The mixed-mating species with relatively low inherent genetic diversity, such as eastern white cedar, can perhaps tolerate better negative effects (increased inbreeding, decreased genetic diversity and $N_{e}$ ) than the predominantly outcrossing species with relatively high genetic diversity, such as Sitka spruce. However, this aspect remains to be further tested in more details globally.

\section{$S p$ statistics and gene dispersal distance}

In agreement with the SGS results estimated using Smouse and Peakall's [12] autocorrelation coefficient method, average value for $S p$ statistic was also higher in peripheral than in core populations of eastern white cedar. Vekemans and Hardy [20] reported significantly higher levels of $S p$ value in populations with low density as compared to the populations with high density. Since the density of trees in the peripheral populations was much lower than in the core ones, the effect of density on the results of $S p$ cannot be ruled out. Except in the population PA, $S p$ values observed in the other three populations of eastern white cedar were higher than the average value observed in five wind-dispersed temperate trees $(S p=0.012)$ and 18 outcrossing plant species [20]. However, it was lower in eastern white cedar as compared to the average value $(S p=0.037)$ of seven mixed mating species [20]. De-Lucas et al. [7] reported higher $S p$ values in fragmented than in continuous populations of another conifer species, Pinus pinaster, and they explained that the lower effective population size due to few reproductive individuals in fragmented populations may have resulted in restricted gene flow via seed and increased the level of SGS in the populations. This explanation may also be applicable to eastern white cedar because the peripheral populations were highly affected by anthropogenic fragmentation. The average gene flow distance in eastern white cedar was higher in peripheral populations than in the core ones. Higher gene flow distances would be expected in fragmented and peripheral populations than in core and intact populations because of lower tree density in peripheral populations resulting in lower obstruction for pollen movement $[20,69]$, which is the case in peripheral populations of eastern white cedar. In agreement with our results, Vekemans and Hardy [20] also reported higher gene flow distances in low density populations than in populations with high density.

\section{Evolutionary potential and genetic resource conservation implications}

The results of genetic diversity, Ne and SGS comparisons in core versus peripheral populations suggest that the evolutionary potential of the studied peripheral eastern white cedar populations may have been adversely affected. The results of our study have significance and implications for conservation and management of genetic resources of eastern white cedar - a declining to endangered species in Atlantic Canada. For ex-situ conservation via seed and vegetative propagule collection, a minimum distance of 75 meters in peripheral and $20 \mathrm{~m}$ in core populations is advisable to capture maximum genetic diversity and avoid sampling genetically-related trees. The core populations in New Brunswick should be conserved in-situ. Both of the peripheral Nova Scotia populations have suffered genetic degradation as a result of extensive human disturbance and edge effect. Here, both ex-situ and in-situ genetic resource conservation efforts supplemented with genetic restoration will be required given that eastern white cedar is a red-listed species in Nova Scotia. The results of our study are relevant for within-population sampling of individuals for population genetic studies in this species. The results may also be applicable for conservation and management of genetic resources of other long-lived, declining species with similar mixed-mating characteristics. 


\section{Conclusions}

In conclusion, our results clearly demonstrate that the studied eastern white cedar populations have significant fine-scale genetic structure at short distances. Peripheral populations have several-folds higher within-population fine-scale genetic structure than core populations. Vegetative propagation does not apparently contribute to SGS in eastern white cedar. Anthropogenic disturbances and fragmentation presumably have significant effects on fine-scale genetic structure in eastern white cedar. The magnitude of evolutionary forces such as founder effect, genetic drift, gene flow and selection, operating in core versus peripheral populations is likely to be different. This may be the first report comparing SGS in intact core versus fragmented peripheral populations of a long-lived, mixed-mating declining plant. The results of our study contribute to the knowledge of poorlyunderstood spatial genetic structure of core versus peripheral populations in plants.

\section{Abbreviations \\ $A_{T}$ : Total number of alleles; $A$ : Mean number of alleles per locus; $A_{\mathbf{E}}$ : Effective number of alleles; $A_{R}$ : Allelic richness; $A_{p}$ : Number of private alleles; b-log $(\wedge \mathrm{bF})$ : Slope of the regression of kinship with In(dist); CL: Cedar Lake; D: Census density; De: Effective density; ED: Emundston; F: Fixation index; Fij: Mean kinship coefficient; GPS: Geographical positioning system; GA: Observed genotype additivity (richness); GA $A_{E}$ : Expected genotype additivity; $\mathrm{H}_{\mathrm{O}}$ : Observed heterozyogosity; $\mathrm{H}_{\mathrm{E}}$ : Expected heterozygosity; Nb: Wright's neighbourhood size; Ne: Effective population size; PA: Perth Andover; $r$ : Spatial autocorrelation coefficients; RL: Rockland; Sp: Sp statistics; og: Estimate of gene flow distance from Sp; SGS: Spatial genetic structure}

\section{Acknowledgements}

We thank Tony Duke of the Nova Scotia Department of Natural Resources for drawing our attention to eastern white cedar conservation genetic issues. We also thank Lawrence Benjamin of Nova Scotia Department of Natural Resources, Michael H. McDonald of New Brunswick Department of Natural Resources and Brenda Tse for their help with the field work and Brenda Tse and Sandra Tucker for their laboratory assistance. Our sincere thanks go to Dr. Lisa O'Connell, who conducted field sampling, DNA extraction and genotyping work for two of the four populations sampled in this study. The research was funded by the research grants provided by the Nova Scotia Department of Natural Resources, PEl Model Forest Network Partnerships Ltd., Canada Research Chair Program (CRC950-201869) funds and the Natural Sciences and Engineering Research Council of Canada Discovery Grant (RGPIN 170651) to O.P. Rajora.

\section{Author details}

${ }^{1}$ Canadian Genomics and Conservation Genetics Institute, Faculty of Forestry and Environmental Management, University of New Brunswick, 28 Dineen Drive, Fredericton, NB E3B 5A3, Canada. ${ }^{2}$ Current address: Department of Plant and Soil Science, Texas Tech University, 15th and Detroit Avenue, Lubbock, Texas 79409, USA.

\section{Authors' contributions}

Both authors have contributed significantly to the work reported in the manuscript. MP was a Postdoctoral Fellow, who generated $50 \%$ of the eastern white cedar genotype data, performed data analysis, and drafted the manuscript. OPR is the principal investigator of the project and contributed to the conception of the study and its experimental design, provided overall guidance and direction and funding, and revised the manuscript. Both authors have read and approved the final manuscript.
Received: 18 October 2011 Accepted: 5 April 2012

Published: 5 April 2012

\section{References}

1. Aitken SN, Yeaman S, Holliday JA, Wang T, Curtis-McLane S: Adaptation, migration or extirpation: climate change outcomes for tree populations. Evol Appl 2008, 1:95-111.

2. Eckert CG, Samis KE, Lougheed SC: Genetic variation across species' geographical ranges: the central-marginal hypothesis and beyond. $\mathrm{Mol}$ Ecol 2008, 17:1170-1188.

3. Lesica P, Allendorf FW: When are peripheral populations valuable for conservation? Conserv Biol 1995, 9:753-760.

4. Hampe A, Petit RJ: Conserving biodiversity under climate change: the rear edge matters. Ecol Letters 2005, 8:461-467.

5. Williams DA, Wang Y, Borchetta M, Gaines MS: Genetic diversity and spatial structure of a keystone species in fragmented pine rockland habitat. Biol Conserv 2007, 138:256-268.

6. Born C, Hardy OJ, Chevalier MH, Ossari S, Attéke EJW, Hossaert-Mckey M: Small-scale spatial genetic structure in the central African rainforest tree species Aucoumea klaineana: a stepwise approach to infer the impact of limited gene dispersal, population history and habitat fragmentation. Mol Ecol 2008, 17:2041-2050.

7. De-Lucas Al, Gonza'lez-Marti'nez SC, Vendramin GG, Hidalgo E, Heuertz M: Spatial genetic structure in continuous and fragmented populations of Pinus pinaster Aiton. Mol Ecol 2009, 18:4564-4576.

8. Gapare WJ, Aitken SN: Strong spatial genetic structure in peripheral but not core populations of Sitka spruce [Picea sitchensis (Bong.) Carr.]. Mol Ecol 2005, 14:2659-2667.

9. Jain SK: Population structure and the effects of breeding system. In Plant Genetic Resources: Today and Tomorrow. Edited by: Frankel O, Hawkes JG. Cambridge Univ. Press, Cambridge, UK; 1975:15-36.

10. Loveless MD, Hamrick JL: Ecological determinants of genetic structure in plant populations. Ann Rev Ecol Syst 1984, 15:65-95.

11. Hamrick $J$, Nason JD: Consequence of dispersal in plants. In Population Dynamics in Ecological Space and Time. Edited by: Rhodes OE, Ronald KC, Smith MH. The University of Chicago Press, Chicago, USA; 1996:203-235.

12. Smouse PE, Peakall R: Spatial autocorrelation analysis of individual multiallele and multilocus genetic structure. Heredity 1999, 82:561-573.

13. Kalisz S, Nason JD, Hanzawa FM, Tonsor SJ: Spatial population genetic structure in Trillium grandiflorum: the roles of dispersal, mating, history and selection. Evol Biol 2001, 55:1560-1568.

14. Young AG, Merriam HG: Effects of forest fragmentation on the spatial genetic structure of Acer saccharum Marsh (sugar maple) populations. Heredity 1994, 72:201-208.

15. Jump AS, Peñuelas J: Genetic effects of chronic habitat fragmentation in a wind-pollinated tree. Proc Natl Acad Sci 2006, 103:8096-8100.

16. Epperson BK: Plant dispersal, neighbourhood size and isolation by distance. Mol Ecol 2007, 16:3854-3865.

17. Troupin D, Nathan R, Vendramin GG: Analysis of spatial genetic structure in an expanding Pinus halepensis population reveals development of fine-scale genetic clustering over time. Mol Ecol 2006, 15:3617-3630.

18. Wright S: Isolation by distance. Genetics 1943, 28:114-138.

19. Reusch TBH, Hukriede W, Stam WT, Olsen JL: Differentiating between clonal growth and limited gene flow using spatial autocorrelation of microsatellites. Heredity 1999, 83:120-126.

20. Vekemans $X$, Hardy OJ: New insights from fine-scale spatial genetic structure analyses in plant populations. Mol Ecol 2004, 13:921-934.

21. Boyle TJB, Liengsiri C, Piewluang C: Genetic structure of black spruce on two contrasting sites. Heredity 1990, 65:393-399.

22. Epperson BK, Allard RW: Spatial autocorrelation analysis of the distribution of genotypes within populations of lodgepole pine. Genetics 1989, 121:369-377.

23. Knowles P: Spatial genetic structure within two natural stands of black spruce (Picea mariana (Mill.) B. S. P.). Silvae Genet 1991, 40:13-19.

24. Knowles $P$, Perry DJ, Foster HA: Spatial genetic structure in two tamarack (Larix laricina (Du Roi) K. Koch) populations with differing establishment histories. Evolution 1992, 46:572-576.

25. Xie CY, Knowles P: Spatial genetic substructure within natural populations of jack pine (Pinus banksiana). Can J Bot 1991, 69:547-551. 
26. Leonardi S, Raddi S, Borghetti M: Spatial autocorrelation of allozyme traits in a Norway spruce (Picea abies) population. Can J For Res 1996, 26:63-71.

27. Epperson BK, Chung MG: Spatial genetic structure of allozyme polymorphisms within populations of Pinus strobus (Pinaceae). Am J Bot 2001, 88:1006-1010.

28. Parker KC, Hamrick JL, Parker AJ, Nason JD: Fine-scale genetic structure in Pinus clausa (Pinaceae) populations: effects of disturbance history. Heredity 2001, 87:99-113.

29. Bucci G, Menozzi P: Spatial autocorrelation and linkage of Mendelian RAPD markers in a population of Picea abies Karst. Mol ECOl 2002, 11:305-315.

30. González-Martínez SC, Gerber S, Cervera MT, Martínez-Zapater JM, Gil L, Alía R: Seed gene flow and fine-scale structure in a Mediterranean pine (Pinus pinaster Ait.) using nuclear microsatellite markers. Theor Appl Genet 2002, 104:1290-1297.

31. Marquardt PE, Epperson BK: Spatial and population genetic structure of microsatellites in white pine. Mol Ecol 2004, 13:3305-3315.

32. Takahashi T, Tani N, Niiyama K, Yoshida S, Taira H, Tsumura Y: Genetic succession and spatial genetic structure in a natural old growth Cryptomeria japonica forest revealed by nuclear and chloroplast microsatellite markers. For Ecol Manage 2008, 255:2820-2828.

33. Newell RE: Provincial (Nova Scotia) Status report on northern white cedar Thuja occidentalis prepared for the Nova Scotia Department of Natural Resources 2005.

34. Jhonston WF: Thuja occidentalis L.: northern white cedar. In Silvics of North America. 1. Conifers. Edited by: Burns RM, Honkala BH. US Department of Agriculture Forest Service Handbook 654, Washington DC, USA; 1990:580-589.

35. Bentley PA, Smith EC: A study of northern white cedar and jack pine in Nova Scotia. Proc NS Inst Sci 1959, 24:376-398.

36. Xie CY, Dancik BP, Yeh FC: The mating system in natural populations of Thuja orientalis. Can J For Res 1991, 21:333-339.

37. Xie CY, Dancik BP, Yeh FC: Genetic structure of Thuja orientalis. Biochem Syst Ecol 1992, 20:433-441.

38. El-Kassaby YA, Russell J, Ritland K: Mixed mating in an experimental populations of western red cedar, Thuja plicata. J Hered 1994, 85:227-231.

39. Perry DJ, Knowles P, Yeh FC: Allozyme variation of Thuja occidentalis L. in Northwestern Ontario. Biochem Syst Ecol 1990, 18:111-115.

40. Matthes-Sears U, Mattes-Sears SC, Larson DW: Sources of allozymic variation in Thuja occidentalis in southern Ontario, Canada. Silvae Genet 1991, 40:100-105.

41. Lamy S, Bouchard A, Simon J-P: Genetic structure, variability and mating system in eastern white cedar (Thuja occidentalis) populations of recent origin in an agricultural landscape in southern Québec. Can J For Res 1999, 29:1383-1392.

42. Perry DJ, Knowles P: Evidence of high self-fertilization in natural populations of eastern white cedar (Thuja occidentalis). Can J Bot 1990, 68:663-668.

43. O'Connell LM, Ritland K, Thompson SL: Patterns of post-glacial colonization by western redcedar (Thuja plicata, Cupressaceae) as revealed by microsatellite markers. Botany 2008, 86:194-203.

44. O'Connell LM, Ritland CE: Characterization of microsatellite loci in western red cedar (Thuja plicata). Mol Ecol 2001, 9:1920-1922.

45. White E, Hunter J, Dubetz C, Brost R, Bratton A, Edes S, Sahota R: Microsatellite markers for individual tree genotyping: application in forest crime prosecutions. J Chem Tech Biotech 2000, 70:923-926.

46. Nakao Y, Iwata H, Matsumoto A, Tsumura Y, Tomaru N: Highly polymorphic microsatellite markers in Chamaecyparis obtusa. Can J For Res 2001, 31:2248-2251.

47. Peakall R, Smouse PE: GENALEX 6: genetic analysis in Excel. Population genetic software for teaching and research. Mol Ecol Notes 2006, 6:288-295.

48. Gaudet J: FSTAT version 1.2: a computer program to calculate Fstatistics. J Hered 1995, 86:485-486.

49. Rajora OP, Rahman MH, Buchert GP, Danick BP: Microsatellite DNA analysis of genetic effects of harvesting in old-growth eastern white pine (Pinus storbus) in Ontario. Mol Ecol 2000, 9:339-348.

50. Raymond M, Rousset F: GENEPOP version 1.2: population genetics software for the exact tests and ecumenicism. J Hered 1995, 86:248-249.
51. Beerli P, Felsenstein J: Maximum likelihood estimation of migration rates and population numbers of two populations using a coalescent approach. Genetics 1999, 152:763-773.

52. Ripley BD: The second-order analysis of stationary point processes. J Appl Prob 1976, 13:255-266.

53. Ripley BD: Modelling spatial patterns. J R Stat Soc 1977, B39:172-212.

54. Perry GLW: SpPack: spatial point pattern analysis in Excel using Visual Basic for Applications (VBA). Environ Model Soft 2004, 19:559-569.

55. Oddou-Muratorio S, Demesure-Musch B, Pelissier R, Gouyon PH: Impacts of gene flow and logging history on the local genetic structure of a scattered tree species, Sorbus torminalis L. Crantz. Mol Ecol 2004, 13:3689-3702

56. Smouse PE, Peakall R, Gonzales E: A heterogeneity test for fine-scale genetic structure. Mol Ecol 2008, 17:3389-3400.

57. Loiselle BA, Sork VL, Nason J, Graham C: Spatial genetic-structure of a tropical understory shrub, Psychotria officinalis (Rubiaceae). Am J Bot 1995, 82:1420-1459.

58. Hardy OJ, Vekemans X: SPAGEDi: a versatile computer program to analyse spatial genetic structure at the individual or population levels. Mol Ecol Notes 2002, 2:618-620.

59. Pandey M, Rajora OP: Genetic diversity and differentiation of core versus peripheral populations of eastern white cedar, Thuja occidentalis $L$. (Cupressaceae). Am J Botany 2012, 99:690-699.

60. Knowles P, Furnier GR, Aleksiuk MA, Perry DJ: Significant levels of selffertilization in natural populations of tamarack. Can J Bot 1987, 65:1087-1091.

61. Levin DA, Kerster HW: Gene flow in seed plants. In In Evolutionary Biology 7. Edited by: Dobzhansky T, Hecht MT, Steere WC. New York: Plenum Press; 1974:139-220

62. Schuster WSF, Mitton JB: Paternity and gene dispersal in limber pine (Pinus flexilis James). Heredity 2000, 84:348-361.

63. Fowells HA: Silvics of forest trees of the United States. U. S. Department of Agriculture Agriculture Handbook 271; 1965.

64. De Blois S, Bouchard A: Dynamics of Thuja occidentalis in an agricultural landscape of southern Quebec. J Veg Sci 1995, 6:531-542.

65. Chung MG, Epperson BK: Clonal and spatial genetic structure in Eurya emarginata (Theaceae). Heredity 2000, 84:170-177.

66. Parker KC, Parker AJ, Beaty M, Fuller MM, Faust TD: Population structure and spatial pattern of two coastal populations of Ocala sand pine (Pinus clausa (Chapm. ex Engelm.) Vasey ex Sarg. var. clausa D. B. Ward). J Torr Bot Soc 1997, 124:22-33.

67. Trabaud L, Michels C, Grosman J: Recovery of burnt Pinus halepensis Mill. forests. II. Pine reconstitution after wildfire. For Ecol Manage 1985 , 113:67-179.

68. McCullough DG, Werner RA, Neumann D: Fire and insects in northern and boreal forest ecosystems of North America. Ann Rev Entomol 1998, 43:107-127.

69. O'Connell L, Mosseler A, Rajora OP: Extensive long-distance pollen dispersal in a fragmented landscape maintains genetic diversity in white spruce. J Heredity 2007, 98:640-645.

doi:10.1186/1471-2148-12-48

Cite this article as: Pandey and Rajora: Higher fine-scale genetic structure in peripheral than in core populations of a long-lived and mixed-mating conifer - eastern white cedar (Thuja occidentalis L.). BMC Evolutionary Biology 2012 12:48. 